\title{
EFEKTIVITAS TEKNIK MODELING DALAM MENINGKATKAN RASA PERCAYA DIRI SANTRI DI PONDOK PESANTREN ASSALAFI AL-FITHRAH SURABAYA
}

\author{
Muhammad Wildan Romdhoni ${ }^{1}$, Nurul Faizah Kamarudin ${ }^{2}$ \\ Pascasarjana UIN Sunan Kali Jaga, Yogyakarta 555181, Indonesia ${ }^{1}$ \\ Pascasarjana UIN Sunan Kali Jaga, Yogyakarta 555181, Indonesia ${ }^{2}$ \\ hudansbook@yahoo.co.id ${ }^{1}$; nurul.faizahasbriy@gmail.com ${ }^{2}$
}

Received : ; Accepted :

; Published :

\begin{abstract}
This research is motivated by the inequality of character development of students, particularly confidence when speaking in public. This study aims to answer the problem formulation which is reflected in the research hypothesis that modelling techniques effective in increasing the confidence of students in Pondok Pesantren Assalafi Al-Fithrah Surabaya (Ha). The approach used is a quantitative approach with the research methods true experimental design, pretest-posttest control group design. Samples were taken by purposive from the population are students of class Isti'dad Ulya $A$ and $B$. The results of data analysis showed that the modeling techniques effective in improving students confidence when speaking in public in Pondok Pesantren Assalafi AlFithrah Surabaya.
\end{abstract}

Keywords: Modeling Techniques, Self Confidence

Pendidikan yang diselenggarakan oleh pemerintah saat ini menuntut siswa untuk mempunyai karakter yang baik sesuai dengan harapan pemerintah dan tentu akan sangat bermanfa'at bagi siswa itu sendiri. Salah satu karakter baik yang diharapkan ada pada setiap pelajar dan siswa di seluruh pelosok negeri adalah karakter percaya diri.

Percaya diri adalah sikap yang dapat ditumbuhkn dari sikap sanggup berdiri sendiri, sanggup untuk menguasai diri sendiri dan bebas dari pengendalian orang lain dan bagaimana seseorang menilai diri sendiri sama seperti orang lain menilai dirinya, sehingga ia akan merasa mampu menghadapi situasi apapun. 
Percaya diri menjadi hal yang sangat esensial yang harus ada pada diri sesorang. Bergitu pentingnya rasa percaya diri sampai banyak motivator dan penulis buku terkenal menyatakan bahwa rasa percaya diri merupakan salah satu hal esensial yang diperlukan seseorang untuk meraih kebahagiaan yang dengan kebahagiaan itu seseorang dapat mencapai kesuksesan adalah kepercayaan diri.

Lembaga pendidikan formal maupun informal merupakan salah satu sarana penting demi berlangsungnya pendidikan karakter yang baik sesuai yang diharapkan pemerintah. Salah satunya adalah Pendidikan Diniyah Formal (PDF) Ulya Al-Fithrah Surabaya yang merupakan sekolah Islam unggulan di daerah Surabaya dan tercatat sebagai bagian dari Yayasan Podok Pesantren Assalafi AlFithrah Surabaya. Berbagai bidang ilmu diajarkan semaksimal mungkin, termasuk menanamkan karakter baik dalam diri anak didiknya, salah satunya adalah rasa percaya diri.

Upaya PDF Ulya Al-Fithrah dalam meningkatkan rasa percaya diri santri salah satunya adalah dengan melatih santri untuk berbicara di depan umum melalui kegiatan ekstrakulikuler bahasa Arab dan Inggris. Meski demikian, kegiatan ekstrakulikuler bahasa yang diadakan empat hari setiap minggu ini terbilang kurang efisien mengingat jumlah santri yang begitu banyak sehingga tidak semua santri dapat mengikuti ekstrakulikuler bahasa yang mengakibatkan hanya sedikit dari sekian banyak santri yang dapat melatih skil bahasanya khususnya dalam berbicara. Hal ini dikarenakan minimnya Sumber Daya Manusia (SDM) dalam berbahasa serta tidak adanya ruanan tetap untuk kegiatan 
ekstrakulikuler bahasa, sehingga mengakibatkan terbatasnya santri yang diterima untuk mengikuti ekstrakulikuler bahasa.

Fenomena ini berdampak pada kurangnya rasa percaya diri santri dan skil berbicara di depan umum, seperti yang dirasakan oleh santri kelas Isti' dad Ulya Pendidikan Diniyah Formal (PDF) Ulya Al-Fithrah, Pondok Pesantren Assalafi Al-Fithrah Surabaya. Salah satu penyebabnya adalah semua santri kelas tersebut masih termasuk santri baru yang masih dalam tahap adaptasi dengan lingkungan pesantren. Tidak hanya itu, kurangnya minat dan keberanian mereka untuk mengikuti kegiatan ekstrakulikuler terutama ekstrakulikuler Bahasa juga berandil besar dalam membuat karakter percaya diri santri tidak berkembang.

Dalam hal ini, ada banyak cara yang dapat dilakukan untuk meningkatkan rasa percaya diri santri, salah satunya adalah dengan melakukan sesi konseling dengan berbagai pendekatan dan teknik yang bisa digunakan. Salah satu teknik yang dapat digunakan dalam sesi konseling adalah teknik modeling.

Teknik modeling adalah teknik konseling dalam pendekatan behavioral yang berakar dari teori Albert Bandura dalam teori belajar sosial, yaitu teknik untuk merubah, menambah maupun mengurangi tingkah laku individu dengan belajar melalui observasi langsung (observational learning) untuk meniru perilaku orang maupun tokoh yang ditiru (model) sehingga individu memperoleh tingkah laku baru yang diinginkan.

Berdasarkan latar belakang di atas, peneliti tertarik untuk melakukan penelitian guna membantu pihak PDF Ulya Al-Fithrah untuk meningkatkan rasa percaya diri santri khususnya di kelas Isti'dad Ulya, dengan melakukan treatment 
konseling menggunakan teknik modeling. Dengan demikian tujuan dari penelitian ini adalah untuk melihat keefektivan teknik modeling dalam meningkatkan rasa percaya diri santri di Pondok Pesantren Assalafi Al-Fithrah Surabaya.

\section{METODE}

Pendekatan penelitian yang digunakan dalam penelitian ini adalah pendekatan kuantitatif dengan memakai jenis desain penelitian eksperimen murni (true experimental design). Bentuk desain eksperimen murni yang dipakai peneliti adalah pretest-posttest control group design.

Populasi subyek dalam penelitian ini adalah seluruh santri kelas Isti'dad Ulya A dan B Pendidikan Diniyah Formal (PDF) Ulya Al-Fithrah. Jumlah santri kelas Isti'dad Ulya A sebanyak 43 santri dan santri kelas Isti' dad Ulya B sebanyak 37 santri, maka jumlah total seluruh anggota populasi sebanyak 80 santri.

Sampel pada penelitian ini berjumlah 60 santri atau $75 \%$ dari jumlah populasi yaitu 80 santri dari dua kelas yang berbeda. Alasan peneliti mengambil sampel sebanyak 60 santri, karena teknik sampling yang dipakai adalah teknik purposive yaitu teknik pengambilan sampel dengan pertimbangan tertentu. Hal ini dikarenakan tidak semua anggota populasi memenuhi kriteria yang telah ditetapkan. Artinya hanya 60 santri yang memenuhi kriteria, sehingga peneliti mengambil sampel hanya 60 santri. Selain menggunakan teknik purposive, pengambilan sampel dilakukan secara proporsional, artinya 30 santri diambil dari kelas Isti' dad Ulya A dan 30 santri diambil dari kelas Isti'dad Ulya B. Selanjutnya 30 santri dari setiap kelas tersebut dibagi kembali kedalam dua kelompok yaitu 
kelompok eksperimen dan control, sehingga masing-masing kelompok memiliki anggota 30 santri.

Teknik sampling yang dipakai peneliti dalam pengambilan sampel menggunakan teknik sampling purposive yang termasuk dalam kelompok nonprobability sampling. Adapun teknik pengumpulan data yang digunakan adalah wawancara, dokumentasi, dan kuesioner (angket).

Data yang diperoleh dari hasil angket, selanjutnya diolah dengan menggunakan rumus statistik deskriptif seperti menghitung mean (nilai rata-rata), median, modus, mencari deviasi standar (simpangan baku), dan lain-lain.

Setelah data diolah dengan rumus statistik deskriptif, selanjutnya data diolah dengan rumus statistik inferensi untuk menguji hipotesis. Pengujian hipotesis dalam penelitian ini melalui perbandingan dari hasil dua kali analisis. Analisis pertama adalah menguji perbedaan rasa percaya diri awal antara kelompok eksperiment dan kelompok kontrol yaitu dari hasil pretest dengan menggunakan rumus t-test untuk sampel terpisah (independent samples $t$-test). Rumusnya adalah sebagai berikut:

$$
t=\frac{M_{a}-M_{b}}{\sqrt{\left(\frac{\sum x_{a}^{2}+\sum x_{b}^{2}}{n_{a}+n_{b}-2}\right)\left(\frac{1}{n_{a}}+\frac{1}{n_{b}}\right)}}
$$

Keterangan:

$$
\begin{array}{ll}
\mathrm{M}_{\mathrm{a}} \text { dan } \mathrm{M}_{\mathrm{b}} & =\text { mean kelompok } \mathrm{a} \text { dan } \mathrm{b} \\
\mathrm{x}_{\mathrm{a}} \text { dan } \mathrm{x}_{\mathrm{b}} & =\text { deviasi kelompok } \mathrm{a} \text { dan } \mathrm{b} \\
\mathrm{n}_{\mathrm{a}} \text { dan } \mathrm{n}_{\mathrm{a}} & =\text { jumlah subyek kelompok } \mathrm{a} \text { dan } \mathrm{b}
\end{array}
$$


Analisis kedua adalah untuk menguji hipotesis yang diajukan. Teknik analisis statistik yang digunakan untuk menguji hipotesis tersebut memakai rumus yang sama seperti rumus diatas.

\section{HASIL}

Untuk menyajikan fakta efektivitas teknik modeling dalam meningkatkan rasa percaya diri santri saat berbicara di depan umum, harus dilakukan analisis melalui dua tahap analisis, hal ini dikarenakan desain penelitian dalam penelitian ini menggunakan pretest-posttest control gorup design.

Analisis tahap pertama adalah menguji perbedaan tingkat percaya diri saat berbicara di depan umum awal (sebelum treatment) antara kelompok eksperimen dan kelompok kontrol. Analisis tahap kedua adalah untuk menguji hipotesis yang diajukan dengan menguji perbadaan tingkat percaya diri saat berbicara di depan umum akhir (setelah treatment) antara kelompok eksperimen dan kelompok kontrol.

Kedua tahap analisis tersebut harus melalui beberapa langkah sebagai syarat, langkah pertama adalah analisis dengan rumus statistik deskriptif untuk mencari mean (rata-rata) dan standard deviation (simpangan baku). Langkah kedua adalah analisis menggunakan rumus statistik inferensia untuk menguji normalitas penyebaran data, dan langkah ketiga adalah analisis menggunakan rumus statistik inferensia (independent sample t-test) untuk menguji hipotesis yang diajukan. Penjelasan tahap dan langkah analisis secara terperinci adalah sebagai berikut: 


\section{A. Analisis Tahap Pertama}

Analisis tahap pertama bertujuan untuk menguji perbedaan tingkat percaya diri santri saat berbicara di depan umum sebelum treatment antara kelompok eksperimen dan kelompok kontrol. Data yang diuji adalah data pretest dari kedua kelompok tersebut. Seperti yang sudah disebutkan diatas, setiap tahap analisis harus melalui langkah-langkah analisis lainnya sebagai syarat, penjelasannya adalah sebagai berikut:

\section{Analisis Statistik Deskriptif}

Analisis ini bertujuan untuk mencari mean (rata-rata) dan standard deviation (simpangan baku). Data yang diperoleh dari pretest kedua kelompok dianalisis dan disajikan dalam bentuk tabel. Hasil analisis deskriptif data pretest kelompok eksperimen adalah:

Rata-rata $\left(\mathrm{M}_{\mathrm{a}}\right)=150.67$

Deviasi $\left(\sum \mathrm{x}_{\mathrm{a}}^{2}\right)=10674.667$

Jumlah responden $\left(\mathrm{n}_{\mathrm{a}}\right)=30$

Sedangkan hasil analisis deskriptif pretest kelompok kontrol adalah:

Rata-rata $\left(\mathrm{M}_{\mathrm{a}}\right)=152.47$

$\operatorname{Deviasi}\left(\sum \mathrm{x}_{a}^{2}\right)=3601.467$

Jumlah responden $\left(\mathrm{n}_{\mathrm{a}}\right)=30$

2. Uji Normalitas

Uji normalitas dilakukan dengan tujuan untuk mengetahui apakah data bersitribusi normal atau tidak. Hala ini diperlukan karena dalam statisti parametrik distribusi data yang normal adalah suatu keharusan dan 
merupakan syarat mutlak yang harus terpenuhi. Uji normalitas dalam penelitian ini menggunakan uji shapiro-wilk menggunakan aplikasi IBM Statistical Package for the Social Sciences (SPSS) versi 23.0 windows. Uji normalitas ini dapat dilakukan secara bersamaan untuk dua kelompok (kontrol dan eksperimen).

Pada uji shapiro-wilk, data yang berdistribusi normal adalah data yang nilai 'sig' lebih besar dari 0.05 pada taraf signifikansi 5\%. Untuk lebih jelasnya, hasil penghitungan uji normalitas dengan menggunakan uji shapirowilk dengan memakai aplikasi IBM SPSS versi 23 windows terhadap data pretest adalah sebagai berikut:

Tabel 1. Tests of Normality Menggunakan Shapiro-Wilk

\begin{tabular}{|c|c|c|c|c|c|c|c|}
\hline \multirow{2}{*}{\multicolumn{2}{|c|}{ Kelompok }} & \multicolumn{3}{|c|}{ Kolmogorov-Smirnov } & \multicolumn{3}{|c|}{ Shapiro-Wilk } \\
\hline & & Statistic & $\mathrm{df}$ & Sig. & Statistic & $\mathrm{df}$ & Sig. \\
\hline \multirow{2}{*}{ PD } & Eksperimen & 0.105 & 30 & $.200^{*}$ & 0.984 & 30 & 0.926 \\
\hline & Kontrol & 0.119 & 30 & $.200^{n}$ & 0.969 & 30 & 0.505 \\
\hline
\end{tabular}

Dari tabel hasil penghitungan uji normalitas pada data hasil pretest menggunakan uji shapiro-wilk di atas, dapat diketahui bahwa kelompok eksperimen memperoleh nilai signifikansi 0.926 dan kelompok kontrol memperoleh nilai 0.505 . Hasil tersebut menunjukan bahwa nilai signifikansi kelmpok eksperimen dan kelompok kontrol > 0.05, maka dapat disimpulkan bahwa data hasil pretest kelompok eksperimen dan kelompok kontrol berdistribusi normal.

3. Uji Hipotesis 
Uji hipotesis bertujuan untuk mencari perbedan rata-rata hasil pretest kelompok eksperimen dan kelompok kontrol dengan harapan tidak ada perbedaan yang signifikan antara tingkat percaya diri saat berbicara di depan umum awal kelompok eksperimen dan kelompok kontrol. Adapun hipotesis yang diajukan adalah sebagai berikut:

$\mathrm{H}_{0}=$ Tidak ada perbedaan rata-rata antara tingkat percaya diri saat berbicara di depan umum kelompok eksperimen dan kelompok kontrol

$\mathrm{H}_{\mathrm{a}}=$ Terdapat perbedaan rata-rata antara tingkat percaya diri saat berbicara di depan umum kelompok eksperimen dan kelompok kontrol

Rumus uji hipotesis yang dipakai dalam penelitian ini adalah uji independet sample t-test dengan rumus sebagai berikut:

$$
t=\frac{M_{a}-M_{b}}{\sqrt{\left(\frac{\sum x_{\mathrm{a}}^{2}+\sum x_{b}^{2}}{n_{\mathrm{a}}+n_{b}-2}\right)\left(\frac{1}{n_{a}}+\frac{1}{n_{b}}\right)}}
$$

Keterangan:

$\mathrm{M}_{\mathrm{a}}$ dan $\mathrm{M}_{\mathrm{b}}=$ mean kelompok $\mathrm{a}$ dan $\mathrm{b}$

$\mathrm{x}_{\mathrm{a}}$ dan $\mathrm{x}_{\mathrm{b}}=$ deviasi kelompok $\mathrm{a}$ dan $\mathrm{b}$

$\mathrm{n}_{\mathrm{a}}$ dan $\mathrm{n}_{\mathrm{a}}=$ jumlah subyek kelompok a dan $\mathrm{b}$.

Derajat kebebasan (db) untuk tes signifikansi dengan menggunakan uji independent sample t-test ini adalah $\left(\mathrm{n}_{\mathrm{a}}+\mathrm{n}_{\mathrm{b}}-2\right)$ atau $(30+30-2)=58$. Agar hasil penghitungan tersebut dapat dikatakan signifikan atas dasar taraf signifikansi 5\% atau 0.05, maka nilai-t yang diperoleh harus sama atau melebihi $\geq 2.00172$ atau dapat dibulatkan menjadi 2.002 . 
Hasil yang didapatkan dari penghitungan menggunakan uji independent sample t-test menunjukan bahwa nilai-t yang didapat sebesar 0.444, nilai tersebut jauh lebih kecil dari pada nilai-t $t_{\text {tabel }}$ pada taraf signifikansi 5\% atau 0.05 sebesar 2.002. Atas dasar hal tersebut maka dapat diambil kesimpulan bahwa $\mathrm{t}_{\text {hitung }}<\mathrm{t}_{\text {tabel }}$, dengan demikian $\mathrm{H}_{\mathrm{a}}$ ditolak dan $\mathrm{H}_{0}$ diterima yaitu tidak ada perbedaan rata-rata antara tingkat percaya diri saat berbicara di depan umum antara kelompok eksperimen dan kelompok kontrol.

\section{B. Analisis Tahap Kedua}

Analisis tahap kedua bertujuan untuk menguji perbedaan tingkat percaya diri santri saat berbicara di depan umum setelah treatment antara kelompok eksperimen dan kelompok kontrol. Data yang diuji adalah data posttest dari kedua kelompok tersebut. Seperti yang sudah disebutkan diatas, setiap tahap analisis harus melalui langkah-langkah analisis lainnya sebagai syarat, penjelasannya adalah sebagai berikut:

\section{Analisis Statistik Deskriptif}

Hasil analisis deskriptif posttest kelompok eksperimen adalah:

Rata-rata $\left(\mathrm{M}_{\mathrm{a}}\right)=160.53$

Deviasi $\left(\sum \mathrm{x}_{\mathrm{a}}^{2}\right)=1963.46667$

Jumlah responden $\left(\mathrm{n}_{\mathrm{a}}\right)=30$

Hasil analisis deskriptif posttest kelompok control adalah:

Rata-rata $\left(\mathrm{M}_{\mathrm{a}}\right)=153.8$

Deviasi $\left(\sum \mathrm{x}_{\mathrm{a}}^{2}\right)=1104.8$ 
Jumlah responden $\left(n_{a}\right)=30$

2. Uji Normalitas

Uji normalitas dilakukan menggunakan uji shapiro-wilk tidak dilakukan secara manual, namun menggunakan aplikasi IBM Statistical Package for the Social Sciences (SPSS) versi 23.0 windows. Hasil yang didapatkan adalah sebagai berikut:

Tabel 2. Tests of Normality Menggunakan Shapiro-Wilk

\begin{tabular}{lllllllll}
\hline \multirow{2}{*}{ Kelompok } & \multicolumn{2}{l}{ Kolmogorov-Smirnov $^{\text {a }}$} & \multicolumn{3}{l}{ Shapiro-Wilk } & \\
\cline { 2 - 8 } & & Statistic & df & Sig. & Statistic & df & Sig. \\
\hline \multirow{2}{*}{ Data } & Eksperimen & 0.103 & 30 & $.200^{*}$ & 0.959 & 30 & 0.292 \\
\cline { 2 - 8 } & Kontrol & 0.098 & 30 & $.200^{*}$ & 0.964 & 30 & 0.392 \\
\hline
\end{tabular}

Dari tabel hasil penghitungan uji normalitas pada data hasil posttest menggunakan uji shapiro-wilk di atas, dapat diketahui bahwa kelompok eksperimen memperoleh nilai signifikansi 0.292 dan kelompok kontrol memperoleh nilai 0.392 . Hasil tersebut menunjukan bahwa nilai signifikansi kelmpok eksperimen dan kelompok kontrol > 0.05, maka dapat disimpulkan bahwa data hasil posttest kelompok eksperimen dan kelompok kontrol berdistribusi normal.

3. Uji Hipotesis

Sama seperti uji hipotesis sebelumnya, uji hipotesis ini dilakukan terhadap hasil posttest menggunakan rumus independent sample t-test. Adapun hipotesis yang diajukan adalah sebagai berikut:

$\mathrm{H}_{0}=$ Tidak ada perbedaan rata-rata antara tingkat percaya diri saat berbicara di depan umum kelompok eksperimen dan kelompok kontrol 
$\mathrm{H}_{\mathrm{a}}=$ Terdapat perbedaan rata-rata antara tingkat percaya diri saat berbicara di depan umum kelompok eksperimen dan kelompok kontrol

Dari hasil penghitungan menggunakan uji independent sample t-test diperoleh nilai-t sebesar 3.584, nilai tersebut jauh lebih besar dari pada nilai$\mathrm{t}_{\text {tabel }}$ pada taraf signifikansi $5 \%$ atau 0.05 sebesar 2.002. Atas dasar hal tersebut maka dapat diambil kesimpulan bahwa $t_{\text {hitung }}>t_{\text {tabel }}$, dengan demikian $\mathrm{H}_{\mathrm{a}}$ diterima dan $\mathrm{H}_{0}$ ditolak yaitu ada perbedaan rata-rata antara tingkat percaya diri saat berbicara di depan umum antara kelompok eksperimen dan kelompok kontrol.

\section{PEMBAHASAN}

Hasil yang didapatkan dari penghitungan menggunakan uji independent sample t-test menunjukan bahwa nilai-t yang didapat sebesar -0.444 , nilai tersebut jauh lebih kecil dari pada nilai- $t_{\text {tabel }}$ pada taraf signifikansi $5 \%$ atau 0.05 sebesar 2.002. Atas dasar hal tersebut maka dapat diambil kesimpulan bahwa $t_{\text {hitung }}<t_{\text {tabel, }}$, dengan demikian $\mathrm{H}_{\mathrm{a}}$ ditolak dan $\mathrm{H}_{0}$ diterima yaitu tidak ada perbedaan rata-rata antara tingkat percaya diri saat berbicara di depan umum antara kelompok eksperimen dan kelompok kontrol sebelum diberikan treatment.

Selanjutnya hasil penghitungan menggunakan uji independent sample ttest diperoleh nilai-t sebesar 3.584, nilai tersebut jauh lebih besar dari pada nilai$\mathrm{t}_{\text {tabel }}$ pada taraf signifikansi $5 \%$ atau 0.05 sebesar 2.002. Atas dasar hal tersebut maka dapat diambil kesimpulan bahwa $t_{\text {hitung }}>t_{\text {tabel }}$, dengan demikian $H_{a}$ diterima dan $\mathrm{H}_{0}$ ditolak yaitu ada perbedaan rata-rata antara tingkat percaya diri saat berbicara di depan umum antara kelompok eksperimen dan kelompok kontrol 
setelah kelompok eksperimen diberikan treatment dan kelompok control tidak diberikan treatment.

Hasil tersebut menjadi dasar pengambilan keputusan pada hipotesis penelitian yang diajukan dalam penelitian ini yaitu $\mathrm{H}_{\mathrm{a}}$ diterima dan $\mathrm{H}_{0}$ ditolak. Maka kesimpulannya adalah teknik modeling efektif dalam meningkatkan rasa percaya diri santri di Pondok Pesantren Assalafi Al-Fithrah Surabaya yang artinya treatment berupa teknik modeling yang sudah diberikan cukup berhasil dalam meningkatkan rasa percaya diri santri pada kelas Isti'dad Ulya di Pondok Pesantren Assalafi Al-Fithrah Surabaya. Hal ini dibuktikan dengan hasil poengujian hipotesis antara kelompok eksperimen sebelum dan sesudah diberikan treatment dengan kelompok control memiliki perbedaan yang signifikan.

\section{KESIMPULAN}

Pada penelitian efektivitas teknik modeling dalam meningkatkan rasa percaya diri santri di Pondok Pesantren Assalafi Al-Fithrah Surabaya ini, dapat diambil kesimpulan bahwa penggunaan teknik modeling efektif dalam meningkatkan rasa percaya diri santri saat berbicara di depan umum pada santri kelas Isti' dad Ulya Pondok Pesantren Assalafi Al-Fithrah Surabaya.

Hal ini dibuktikan dengan pengambilan keputusan hipotesis $H_{a}$ yaitu teknik modeling efektif dalam meningkatkan rasa percaya diri santri di Pondok Pesantren Assalafi Al-Fithrah Surabaya. Pengambilan keputusan ini diberikan atas dasar nilai $\mathrm{t}_{\text {tabel }}$ pada taraf signifikansi $5 \%$ atau 0.05 yaitu 2.002 lebih kecil dari pada nilai $\mathrm{t}_{\text {hitung }}$ yang didapatkan dari hasil penghitungan uji independent sample t- 
test pada nilai posttest antara kelompok eksperimen dan kelompok kontrol yaitu sebesar 3.584 .

\section{DAFTAR PUSTAKA}

Fatimah, Enung. (2006). Psikologi Perkembangan (Perkembangan Peserta Didik). Bandung: CV. Pustaka Setia.

Fujishin, Randy. (2009). Smart Public Speaker; Seni Berbicara di Muka Umum. Yogyakarta: Bookmarks.

Hadi, Sutrisno. (1990). Metodologi Research Jilid 4. Yogyakarta: Andi Offset.

Hakim, Thursam. (2002). Mengatasi Rasa Tidak Percaya Diri. Jakarta: Puspa Suara.

Komalarasi, Gantina. (2011). dkk. Teori dan Teknik Konseling. Jakarta: Indeks.

Santoso, Singgih. (2015). Menguasai Statisktik Parametrik Konsep dan Aplikasi dengan SPSS. Jakarta: Elex Media Komputindo.

Shaleh, Abdul Rahman. (2004). Psikologi Suatu Pengantar dalam Prespektif Islam. Jakarta: Kencana.

Sugiyono. (2012). Statistika untuk Penelitian. Bandung: Alfabeta.

Suyatno, Agus. (1987). Pendidikan yang Efektif yang Dapat Dilakukan Oleh Keluarga. Surabaya: Media Pendidikan dan Ilmu Pengetahuan.

Wesfix, Tim. (2016). Percaya Diri itu “Dipraktekin”. Jakarta: PT. Grasindo. 